\title{
Conditioning Injury-Induced Spinal Axon Regeneration Fails in Interleukin-6 Knock-Out Mice
}

\author{
William B. J. Cafferty, ${ }^{1}$ Natalie J. Gardiner, ${ }^{2}$ Partha Das, ${ }^{1}$ Jin Qiu, ${ }^{1}$ Stephen B. McMahon, ${ }^{1}$ and Stephen W. N. Thompson ${ }^{3}$ \\ ${ }^{1}$ Centre for Neuroscience Research, Guy's, Kings and St. Thomas' School of Biomedical Science, King's College London, London SE1 1UL, United Kingdom, \\ ${ }^{2}$ School of Biological Sciences, University of Manchester, Manchester M13 9PT, United Kingdom, and ${ }^{3}$ School of Biological Sciences, University of \\ Plymouth, Plymouth PL4 8AA, United Kingdom
}

\begin{abstract}
Regeneration of injured adult sensory neurons within the CNS is essentially abortive, attributable in part to lesion-induced or revealed inhibitors such as the chondroitin sulfate proteoglycans and the myelin inhibitors (Nogo-A, MAG, and OMgp). Much of this inhibition may be overcome by boosting the growth status of sensory neurons by delivering a conditioning lesion to their peripheral branches. Here, we identify a key role for the lesion-induced cytokine interleukin-6 (IL-6) in mediating conditioning lesion-induced enhanced regeneration of injured dorsal column afferents. In adult mice, conditioning injury to the sciatic nerve 1 week before bilateral dorsal column crush resulted in regeneration of dorsal column axons up to and beyond the injury site into host CNS tissue. This enhanced growth state was accompanied by an increase in the expression of the growth-associated protein GAP43 in preinjured but not intact dorsal root ganglia (DRGs). Preconditioning injury of the sciatic nerve in IL-6 - / - mice resulted in the total failure in regeneration of dorsal column axons consequent on the lack of GAP43 upregulation after a preconditioning injury. DRGs cell counts and cholera toxin $\beta$ subunit labeling revealed that impaired regeneration in knock-out mice was unrelated to cell loss or a deficit in tracer transport. In vitro, exogenous IL-6 boosted sensory neuron growth status as evidenced by enhanced neurite extension. This effect required NGF or NT-3 but not soluble IL-6 receptor as cofactors. Evidence of conditioning lesion-enhanced growth status of DRGs cells can also be observed in vitro as an earlier and enhanced rate of neurite extension; this phenomenon fails in IL-6 - / - mice preinjured $7 \mathrm{~d}$ in vivo. We suggest that injury-induced IL-6 upregulation is required to promote regeneration within the CNS. Our results indicate that this is achieved through a boosted growth state of dorsal column projecting sensory neurons.
\end{abstract}

Key words: IL-6 (interleukin-6); CNS; regeneration; conditioning lesion; axotomy; dorsal root ganglia

\section{Introduction}

The balance between two main factors governs the success or failure of axonal regeneration within damaged CNS pathways, namely the presence of a permissive growth environment and, second, the intrinsic growth capacity of the damaged neurons. Evidence exists to suggest that elevating the intrinsic growth status of damaged sensory neurons may overcome much of the inhibition presented by the damaged CNS and result in a degree of regeneration (Oudega et al., 1994; Neumann and Woolf, 1999; Pasterkamp et al., 2001; Neumann et al., 2002; Qiu et al., 2002). One procedure whereby the intrinsic growth capacity of adult neurons may be boosted beyond the normal expected degree is via the conditioning lesion paradigm (McQuarrie and Grafstein, 1973; McQuarrie et al., 1977). This has been particularly well documented with sensory neuron regeneration in which sciatic

Received Aug. 2, 2002; revised March 5, 2004; accepted March 22, 2004.

This work was supported by the Wellcome Trust and Action Research (United Kingdom). We thank Dr. Stephen Hopkins and Prof. Richard Grencis (School of Biological Sciences, University of Manchester, Manchester, UK) for the kind gift of IL-6 + / + and IL- $6-/-$ mice and John Grist and Vivien Cheah for expert technical assistance.

Correspondence should be addressed to Dr. W. B. J. Cafferty, Centre for Neuroscience Research, First Floor Hodgkin Building, Guy's Hospital, Kings College London, London Bridge, London SE1 1UL, UK. E-mail: will.cafferty@kcl.ac.uk.

DOI:10.1523/JNEUROSCI.2245-02.2004

Copyright $\odot 2004$ Society for Neuroscience $\quad$ 0270-6474/04/244432-12\$15.00/0 nerve crush has been shown to augment the capacity of adult dorsal root ganglia (DRGs) neurons to mount a regenerative response after a subsequent injury to their axons. Under these circumstances, enhanced regeneration of both the peripherally directed axon branch as well as that portion of the sensory neuron occupying a CNS environment has been demonstrated (Carlsen, 1983; Richardson and Issa, 1984; Richardson and Verge, 1987; Sjoberg and Kanje, 1990; Chong et al., 1996; Neumann and Woolf, 1999). The impracticality of delivering conditioning lesions to promote CNS repair is patently obvious. Our goal, therefore, must be to understand the nature of the conditioning response in terms of its underlying cellular and molecular mechanisms.

We have previously shown that one member of the gp130 family of injury-induced cytokines, leukemia inhibitory factor (LIF), plays an important role in the conditioning-induced enhancement of neurite outgrowth in a subpopulation of adult sensory neurons in vitro and in vivo (Cafferty et al., 2001). In this study, the effect of LIF appeared specific for the population of calcitonin gene related peptide-expressing small diameter sensory neurons, the majority of which are nociceptors. There is evidence that interleukin-6 (IL-6), a closely related member of the gp130 cytokine family that also includes ciliary neurotrophic factor, oncostatin $\mathrm{M}$, cardiotrophin-1, and cardiotrophin-like cytokine, may also have important growth-promoting properties 
in the damaged adult nervous system independent of its survival effects. IL-6 may be detected in limited amounts in the adult mammalian nervous system under normal circumstances. Sciatic nerve axotomy results in the synthesis of IL- 6 at sites undergoing Wallerian degeneration (Bolin et al., 1995; Zhong and Heuman, 1995; Bourde et al., 1996; Kurek et al., 1996; Reichert et al., 1996) and also by a subpopulation of injured sensory neurons themselves (Murphy et al., 1995). There is increasing evidence that IL-6 has a major role in nerve regeneration. For example, IL-6 knock-out mice have impaired peripheral nerve regeneration (Zhong et al., 1999), whereas mice that constitutively overexpress IL-6 and its soluble receptor (sIL-6R) show enhanced PNS regeneration (Hirota et al., 1996). The gp 130 receptor exists in sensory neurons (Gardiner et al., 2002), and evidence to date suggests that gp130 receptor activation may be an integral component of the enhanced growth state that follows conditioning peripheral nerve lesions (Cafferty et al., 2001; Snider et al., 2002). In this study, we focused on the role that injury-induced IL- 6 may play in the intrinsic growth status and associated regeneration of injured sensory neuron collaterals within ascending dorsal column pathways. Additionally, we designed experiments to determine the effect of exogenous IL-6 on neurite outgrowth of adult rat sensory neurons in vitro. IL-6 expression appears to be absolutely required for conditioning injury-induced regeneration of dorsal column axons after experimental spinal cord injury in vivo. In addition, exogenous IL-6 promotes regeneration of large diameter sensory neurons in vitro in a manner consistent with long axon elongation in vivo.

\section{Materials and Methods}

Neuronal cultures. Primary DRGs cultures were prepared from adult male Wistar rats (B\&K Universal, Hull, UK) or IL- $6+/+$ or $-/$ - mice (a gift from S. Hopkins and R. Grencis, University of Manchester, Manchester, UK) (Kopf et al., 1994), as described previously (Cafferty et al., 2001). Briefly, ganglia were removed from L4 and L5 spinal levels from terminally anesthetized animals, cleared of connective tissue, and chemically dissociated in $0.125 \%$ collagenase (Sigma, Poole, UK) for $1.5 \mathrm{hr}$ at $37^{\circ} \mathrm{C}$ in $5 \% \mathrm{CO}_{2}$. The ganglia were mechanically dissociated by gentle trituration in $1 \mathrm{ml}$ of modified Bottenstein and Sato's medium (BS; serum free) in Ham's F-12 solution (Invitrogen, Renfrew, UK), then centrifuged through 15\% BSA (Sigma) at $600 \mathrm{rpm}$ for $6 \mathrm{~min}$. Dissociated neurons were resuspended in $\mathrm{Ca}^{2+}$ - and $\mathrm{Mg}^{2+}$-free HBSS (Invitrogen), containing $50 \mu \mathrm{g} / \mathrm{ml}$ DNase (type I; Sigma) and $250 \mu \mathrm{g} / \mathrm{ml}$ soybean trypsin inhibitor (type II; Sigma), and diluted in BS to a final concentration of $1500-2500 \mathrm{cells} / \mathrm{ml}$. Cells were cultured under the following conditions: BS alone (control) or BS supplemented with one or more of the following factors: NGF (10 ng/ml), NT3 (10 ng/ml), IL-6 (10 pg to $100 \mathrm{ng} / \mathrm{ml}$; R\&D Systems, Minneapolis, MN), and sIL-6R (10 pg to $100 \mathrm{ng} / \mathrm{ml}$; R\&D Systems). Cells were plated onto Lab-Tek chamber slides (Nunc, Fisher Scientific, Loughborough, UK) coated with poly-L-lysine $(10 \mu \mathrm{g} / \mathrm{ml}$; Sigma) and EHS Laminin (10 $\mu \mathrm{g} / \mathrm{ml}$; Sigma). Cultures were incubated for $18 \mathrm{hr}$ at $37^{\circ} \mathrm{C}$ in a humidified atmosphere containing $5 \% \mathrm{CO}_{2}$.

Immunohistochemistry. Cells were fixed with $2 \%$ ice-cold paraformaldehyde (PFA) solution for $15 \mathrm{~min}$ and then permeabilized with methanol at $-20^{\circ} \mathrm{C}$ for $3 \mathrm{~min}$. A monoclonal antibody against $\beta$ (III) tubulin ( 1 : 1000; Sigma) was used as a pan-neuronal marker. Cells were incubated in primary antibodies for $4 \mathrm{hr}$ and then incubated for $1 \mathrm{hr}$ with Cy3- or FITC-conjugated secondary antibodies (1:200; Jackson ImmunoResearch, West Grove, PA). All incubations were conducted at room temperature.

Culture analysis. Soma that extended neurites greater than two cell body diameters $(>50 \mu \mathrm{m})$ were classified as process-bearing neurons. The mean percentage of neurite-bearing cells was calculated from cell counts from at least four chambers per animal, with at least four animals per experimental group. The average length of the longest neurite was measured from digitized images and quantified using an image analysis program (SigmaScan 4.01.003; SPSS; Jandel Scientific, San Rafael, CA).

Animal surgery. All experiments were undertaken in accordance with the United Kingdom Animals (scientific procedures) Act 1986. Adult male IL- 6 wild-type ( $n=9$; six test and three sham) and knock-out $(n=$ 9; six test and three sham) mice underwent a unilateral axotomy of their left sciatic nerves at mid-thigh level $(n=18 ; 12$ test and 6 sham) under isoflurane anesthesia. Seven days later, animals were either killed and their ganglia removed for culture or they were re-anesthetized and had their dorsal column projection crushed at T6 (thoracic level 6). Briefly, a partial laminectomy was performed at T6 and lignocaine (2\%; Antigen Pharmaceuticals, Roscrea, Ireland) was applied to the exposed spinal cord surface. A small incision was made in the dura mater, and fine watchmakers' forceps were inserted into the spinal cord (medial to the dorsal root entry zones) to a depth of $1 \mathrm{~mm}$ and held together for $10 \mathrm{sec}$ before being removed. Crushing the dorsal columns with blunt forceps leaves the large midline dorsal blood vessel intact while entirely severing axons in the dorsal column projection. Muscle and skin layers were sutured with 4.0 Vicryl (Ethicon, Edinburgh, UK). All animals recovered uneventfully and were killed 4 weeks after the dorsal column crush. Four days before sacrifice, all animals received a unilateral injection of the transganglionic retrograde tracer cholera toxin $\beta$ subunit (CTB; List Biologic, Campbell, CA) to their left sciatic nerve. CTB labels large myelinated $\mathrm{A} \beta$ fibers in the dorsal column and their cell bodies in the DRGs. To minimize additional trauma, the CTB was injected via a heat-pulled glass capillary pipette with an external diameter of $\sim 25 \mu \mathrm{m}$, super-glued to a $10 \mu \mathrm{l}$ Hamilton syringe. Animals were re-anesthetized with isofluorane, the left sciatic nerve was exposed proximal to the axotomy site, $2 \%$ lignocaine was applied briefly, $2 \mu \mathrm{l}$ of a $1 \%$ solution of CTB was delivered over $1 \mathrm{~min}$, and the tip was left in situ for an additional minute before withdrawing. The wound was sutured in layers, and the animals were left to recover. Sterile precautions were maintained throughout.

Tissue processing and immunostaining. All animals were deeply anesthetized with pentobarbitone $(50 \mathrm{mg} / \mathrm{kg}$ ) and perfused transcardially with $25 \mathrm{ml}$ of saline, followed by $200 \mathrm{ml}$ of PFA (4\% in $0.1 \mathrm{M}$ phosphate buffer). Lesioned spinal cord, caudal medulla, and ipsi/contra L4 and L5 DRGs were dissected from the animals. The tissue was postfixed in $4 \%$ PFA for $2 \mathrm{hr}$ at $4^{\circ} \mathrm{C}$ and then transferred to $20 \%$ sucrose overnight at $4^{\circ} \mathrm{C}$. Tissues were embedded in optimal cutting temperature compound $(\mathrm{BDH}$, Essex, UK) on dry ice. Longitudinal sections of spinal cord through the crush site (20 $\mu \mathrm{m}$ thickness), transverse sections through the caudal medulla ( $20 \mu \mathrm{m}$ thickness), and $15 \mu \mathrm{m}$ sections of DRGs were cut on a cryostat and thaw mounted onto Superfrost Plus microscope slides $(\mathrm{BDH})$. All sections were preincubated for $1 \mathrm{hr}$ in $10 \%$ normal donkey serum (NDS, Jackson ImmunoResearch) containing $0.2 \%$ Triton X-100 (Sigma). Sections were immunostained with one or a combination of the following antibodies diluted in 5\% NDS and $0.2 \%$ Triton and incubated overnight at room temperature. Goat anti-CTB (1:2000; List Biological Laboratories), rabbit anti-GFAP (1:4000; Dako, Glostrup, Denmark), rabbit anti-GAP43 (1:2000; a gift from J. V. Priestley, Neuroscience Centre Bart's and the London School of Medicine and Dentistry, Queen Mary University of London, London, UK). After washing, sections were incubated for $2 \mathrm{hr}$ in the following secondary antibodies: donkey antigoat Cy3 (1:200; Jackson ImmunoResearch) or donkey anti-rabbit FITC (1:200; Jackson ImmunoResearch). Slides were coverslipped with Vector Shield (Vector Laboratories, Burlingame, CA), and fluorescence was visualized with an Axioplan microscope (Zeiss, Oberkochen, Germany).

Quantification of fiber growth. Regenerating fibers, visualized by CTB immunoreactivity (-IR), appeared as numerous tangled irregular fiber bundles; this presented difficulty in counting precise numbers and length of regenerating axons. Therefore, we used a densitometric type of analysis (Bradbury et al., 1999). Images of CTB-IR in longitudinal sections of spinal cord through the lesion site were imported into SigmaScan software (SPSS). A threshold level of fluorescent intensity was determined. This threshold level was used throughout analysis of serial sections and across treatment groups. By drawing a band of uniform width along the length of the section, the program determines the average level of fluorescence across this band and how this varies with distance. Therefore, using this function, we can determine what the density of CTB-IR is, 

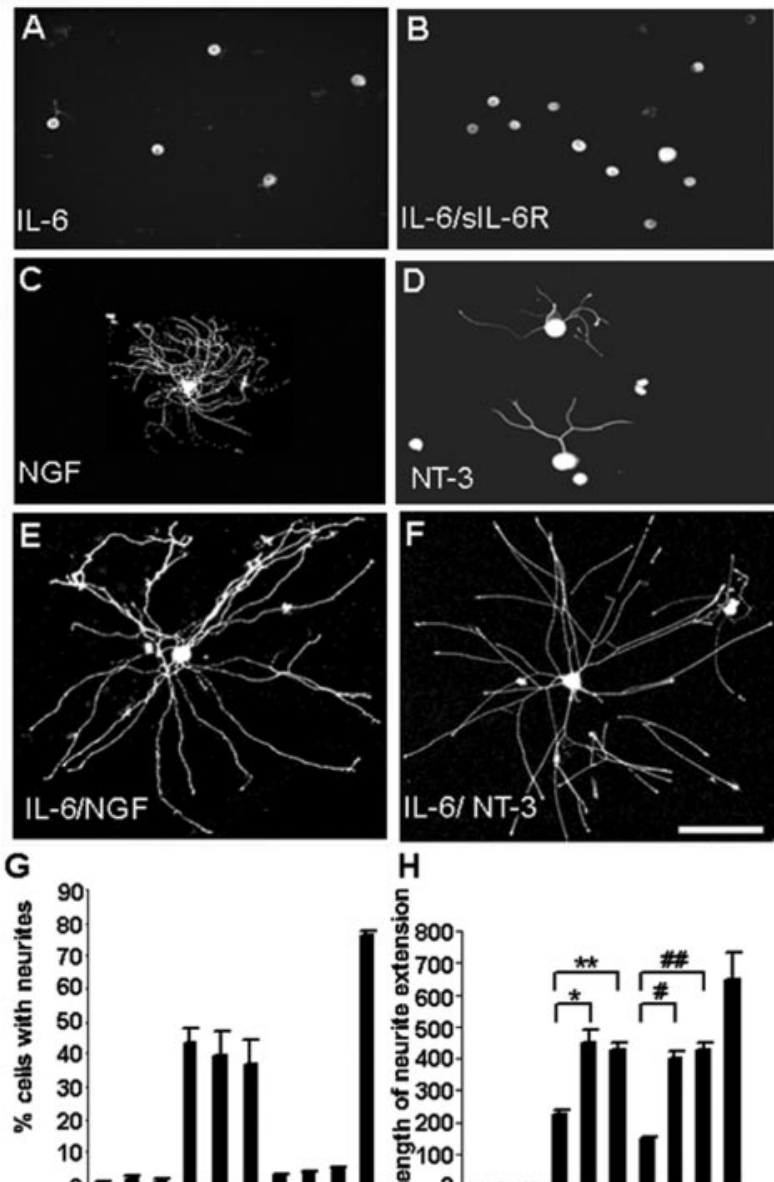

\section{H}
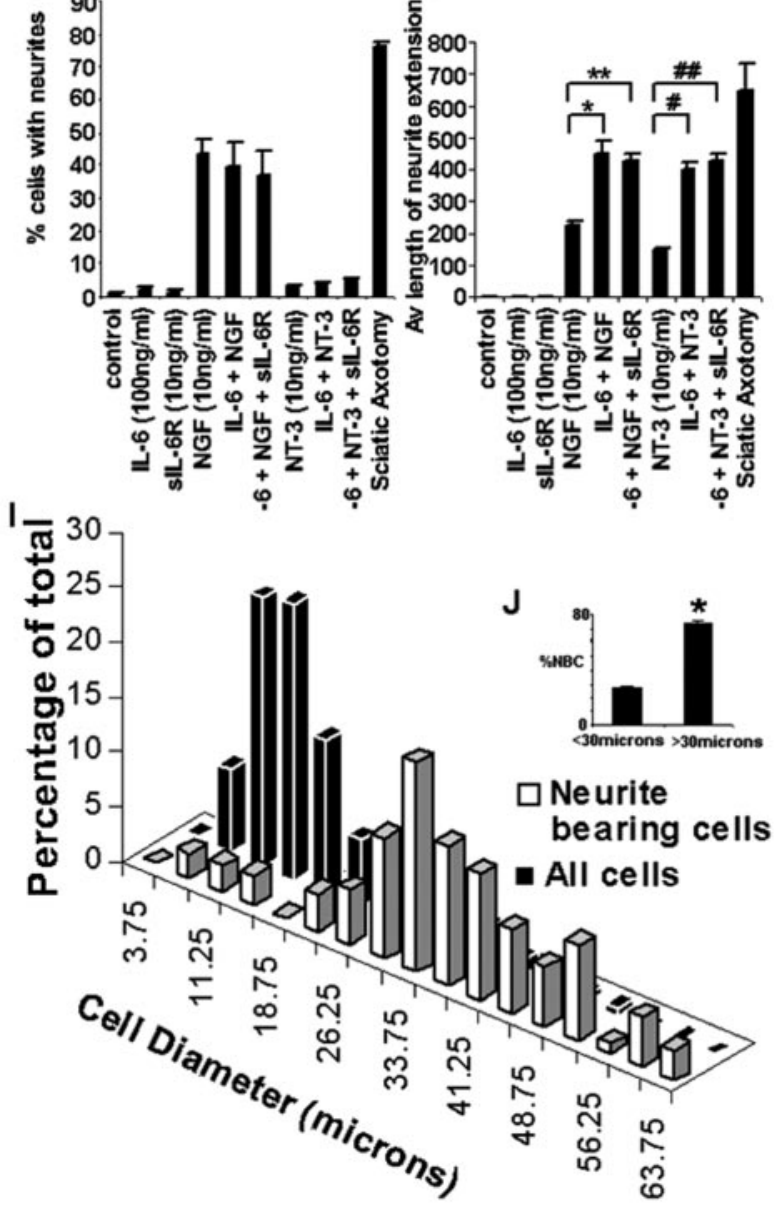

Figure 1. IL-6 does not initiate sprouting of adult rat sensory neurons but induces neurite elongation in the presence of a neurotrophin. $A-F$, Dark-field photomicrographs of cultured adult rat sensory neurons immunocytochemically stained with pan neuronal marker $\beta$ (III) tubulin after $18 \mathrm{hr}$ in vitro, grown in serum-free media supplemented with the factors indicated. Dissociated sensory neurons cultured in the presence of IL-6, either alone $(10 \mathrm{ng} / \mathrm{ml} ; A)$ or in the presence of its soluble receptor $(10 \mathrm{pg} / \mathrm{ml}$ to $100 \mathrm{ng} / \mathrm{ml} ; B)$, failed to exhibit neurite outgrowth after $18 \mathrm{hr}$ in vitro ( $G)$. NGF (10 ng/ml) alone significantly increased the percentage of neurite- proximal and distal to the lesion site. By repeating this protocol on serial ventral to dorsal sections (10 sections $100 \mu \mathrm{m}$ apart) of cord, we can build a three-dimensional picture of regenerating fibers. Data were subjected to two-way ANOVA.

DRGs analysis: cell size distribution. Digital images were captured under the same brightness and contrast settings. Four randomly selected sections of L4/L5 DRGs from each animal were captured and imported into SigmaScan software (SPSS). All sections were digitally outlined, creating an artificial overlay. The average intensity and feret diameter of each profile identified by the overlay was automatically determined. This type of analysis is flawed because it overestimates the numbers of large diameter neurons because of to their increased probability of being included in a section, as well as an overall overestimation of small diameter profiles attributable to off cuts of all neurons. To correct for this, we applied the method of recursive translation (Rose and Rohrlich, 1988) that converts observed neuronal profiles to the cellular population from which they were drawn. Kolmogorov-Smirnov tests were used to determine whether neuronal size frequency distributions differed between populations. Proportions of labeled neurons were compared using twoway ANOVA, followed by appropriate post hoc tests for pairwise differences.

DRGs analysis: GAP43 immunoreactivity. L4 and L5 ganglia were processed for dual immunohistochemistry for CTB (to localized sensory neurons with central branches that form the gracile funiculus) and GAP43 (to determine their growth status). Four randomly selected sections of L5 DRGs from IL- $6+/+(n=6)$ and IL- $6-/-(n=6)$ mice that had received a preconditioning injury or sham surgery $(n=3$ per genotype) were digitally captured under the same brightness and contrast settings and imported into Sigma Scan software. All CTB-IR profiles within the section were outlined, creating an artificial digital layer. This layer was then superimposed on the same section captured under the filter detecting GAP43-IR. The program then determined the optical density of objects defined by the digital overlay.

\section{Results}

IL-6 alone does not initiate neurite outgrowth but induces neurite elongation in the presence of neurotrophic factors Dissociated adult rat sensory neurons remain viable, yet quiescent, for over $24 \mathrm{hr}$ in vitro in the absence of serum and exogenous trophic support (Lindsay, 1988; Cafferty et al., 2001). We used

bearing cells $(C, G)$. The percentage of neurite-bearing cells was not significantly different in the presence of NGF compared with NGF plus IL-6 (1 pg to $100 \mathrm{ng}$ ) or NGF plus IL-6 and its soluble receptor (slL-6R; $10-100 \mathrm{ng} / \mathrm{ml}$; $G)$. NT-3 $(10 \mathrm{ng} / \mathrm{ml})$ alone increased the percentage of neuritebearing cells $(D, G)$; inclusion of IL-6 $(1 \mathrm{pg}$ to $100 \mathrm{ng} / \mathrm{ml})$ alone or in the presence of its soluble receptor $(10-100 \mathrm{ng} / \mathrm{ml})$ failed to recruit an additional population of neurite-bearing cells $(G)$. Preconditioning injury to the sciatic nerve results in neurite extension from $76.65 \%$ of dissociated cells in vitro (G). The addition of IL-6 $(100 \mathrm{ng} / \mathrm{ml})$ alone or in the presence of its soluble receptor $(10 \mathrm{ng} / \mathrm{ml})$ to NGF $(10 \mathrm{ng} / \mathrm{ml})$-treated cultures significantly increased the average length of neurite extension compared with cells grown in the presence of NGF $(10 \mathrm{ng} / \mathrm{ml})$ alone $\left(H^{*}{ }^{*}\right.$ and ${ }^{* *} p<0.001$, ANOVA). The addition of $\mathrm{IL}-6(100 \mathrm{ng} / \mathrm{ml})$ alone or in the presence of its soluble receptor $(10 \mathrm{ng} / \mathrm{ml})$ to NT-3 $(10 \mathrm{ng} / \mathrm{ml})$-treated cultures also significantly increased the average length of neurite extension $(F)$ compared with cells grown in the presence of NT-3 (10 $\mathrm{ng} / \mathrm{ml})$ alone $\left(H_{;} ;\right.$and $\left.^{\# \#} p<0.001, A N O V A\right)$. The level of neurite extension after the co-addition of IL- 6 and NGF/NT-3 was not significantly different from that of cells that had received a preconditioning sciatic nerve lesion $7 \mathrm{~d}$ before plating $(H)$. IL-6 induced neurite elongation in the presence of NT-3 in a subpopulation of large diameter sensory neurons in culture $(I, J)$. The percentage of neurite-bearing cells is low in the presence of NT-3 $(10 \mathrm{ng} / \mathrm{ml})$ alone and is not significantly different when combined with IL-6 6 and its soluble receptor. This effect is preferentially confined to a population of large diameter sensory neurons. The histogram (I) shows the cell size distribution of all cells in vitro and the distribution of neurite-bearing cells in the presence of NT-3 plus IL-6 after $18 \mathrm{hr}$ of culture. The percentage of neurite-bearing cells is small (because of few cells in the lumbar ganglia possessing trkC; McMahon et al., 1994) but is significantly distributed to the larger diameter profiles, with a diameter over $30 \mu \mathrm{m}\left(J ;{ }^{*} p<\right.$ 0.001, ANOVA) \%NBC, Percentage of neurite-bearing cells. Scale bar, $100 \mu \mathrm{m}$. 

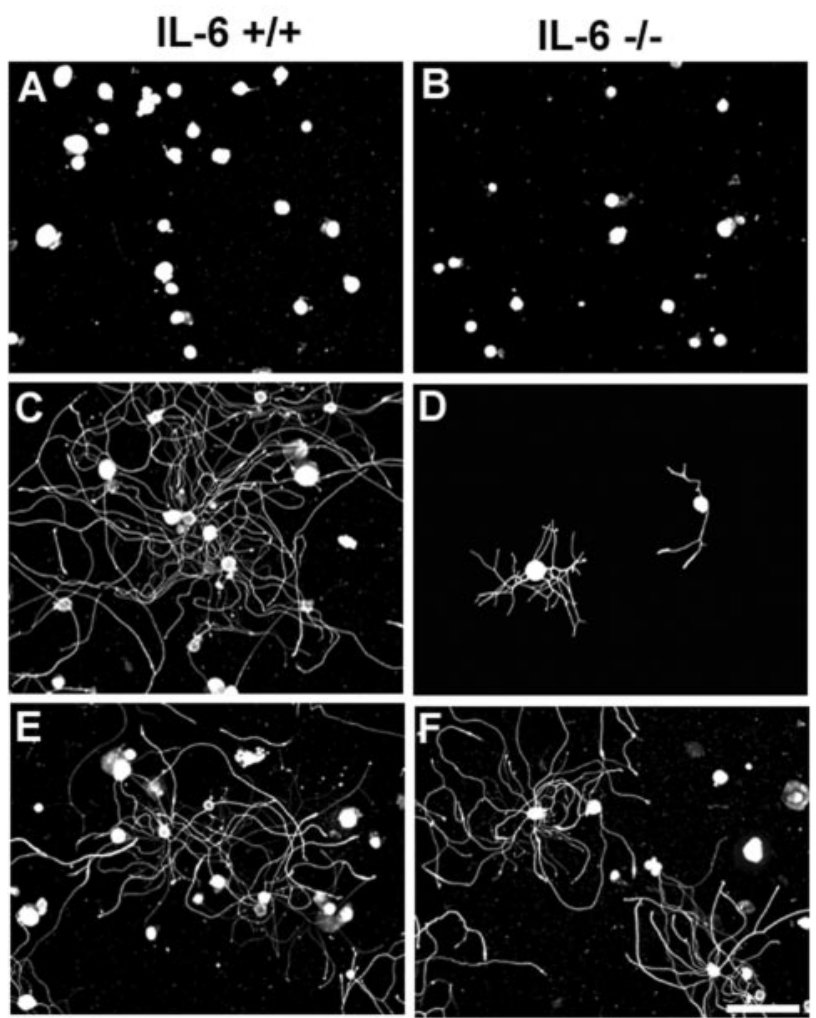

G

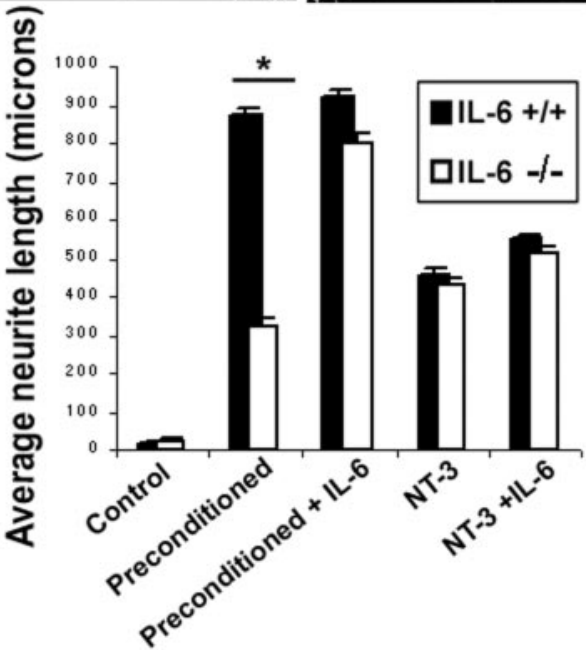

Figure 2. IL-6 - / - mice failed to display enhanced neurite extension after previous conditioning lesion in vitro. $A-F$ illustrate photomicrographs of dissociated adult sensory neurons from IL-6 $+/+(A, C, E)$ and IL-6 - I- $(B, D, F)$ mice after $18 \mathrm{hr}$ in vitro. Cells from $+/+(A, G)$ and $-I-(B, G)$ mice cultured in serum-free media failed to extend neurites after $18 \mathrm{hr}$ in vitro. Cells cultured from IL- $6+/+$ mice that had received a preconditioning lesion to their sciatic nerve $7 \mathrm{~d}$ before plating extended neurites with an average length of $869 \pm 15.6 \mu \mathrm{m}(C, G)$, significantly longer than from IL-6 - / - that had received the same lesion $\left(D, G ;{ }^{*} p<0.001\right.$, ANOVA). Inclusion of $10 \mathrm{ng} / \mathrm{ml} \mathrm{IL-6} \mathrm{to} \mathrm{preinjured} \mathrm{cells} \mathrm{from}-/-$ mice increased the average length of neurite extension $800.2 \pm 21.3 \mu \mathrm{m}(F, G)$, while having no further influence on $+/+$ mice $(E, G)$. Both $+/+$ and $-/-$ mice retained the ability to respond to NT-3 $[10 \mathrm{ng} / \mathrm{ml}$; $455.8 \pm 18.1(+/+)$ vs $431.8 \pm 14.5 \mu \mathrm{m}(-/-) ; G]$ alone and in combination with IL-6 [10 $\mathrm{ng} / \mathrm{ml} ; 553.6 \pm 7.2(+/+)$ vs $510.3 \pm 15.9 \mu \mathrm{m}(-/-)]$ with no significant difference in neurite extension between genotypes. Scale bar, $100 \mu \mathrm{m}$.

this window of growth quiescence to assay the growth-promoting ability of the pleiotropic cytokine IL-6.

Isolated adult rat sensory neurons were cultured for $18 \mathrm{hr}$ in serum-free control media or media supplemented with one or more of the following: IL-6 (10 pg/ml to $100 \mathrm{ng} / \mathrm{ml})$ in the pres- ence or absence of sIL-6R (10 pg/ml to $100 \mathrm{ng} / \mathrm{ml})$, NGF (10 $\mathrm{ng} / \mathrm{ml})$, or NT3 $(10 \mathrm{ng} / \mathrm{ml})$. The percentage of cells initiating neurite outgrowth in control media over the culture period was minimal $(0.93 \pm 0.2 \% ; n=14)$ (Fig. $1 G)$. IL-6 alone, over a range of concentrations ( $10 \mathrm{pg} / \mathrm{ml}$ to $100 \mathrm{ng} / \mathrm{ml} ; n=5$ for each concentration), failed to induce appreciable neurite outgrowth (1.84 \pm $0.74 \%$ of neurons; $n=5 ; 100 \mathrm{ng} / \mathrm{ml}$ ) (Fig. $1 A, G$ ). Inclusion of sIL-6R (10 pg/ml to $100 \mathrm{ng} / \mathrm{ml})$ did not significantly increase the percentage of neurite-bearing neurons $(2.28 \pm 0.46 \% ; n=5 ; 100$ $\mathrm{ng} / \mathrm{ml}$ ) (Fig. $1 B, G$ ). The percentage of cells exhibiting neurite outgrowth in the presence of NGF $(10 \mathrm{ng} / \mathrm{ml})$ was $43.4 \pm 4.32 \%$ $(n=14)$ (Fig. $1 C, G)$. The addition of IL-6 $(10 \mathrm{pg} / \mathrm{ml}$ to 100 $\mathrm{ng} / \mathrm{ml}$ ) to NGF-containing cultures did not significantly increase the percentage of neurite-bearing cells compared with the effect of NGF alone (NGF plus IL-6, $45.6 \pm 12.0 \% ; n=5$ ) (Fig. $1 G$ ). The addition of sIL-6R ( $10 \mathrm{pg} / \mathrm{ml}$ to $100 \mathrm{ng} / \mathrm{ml})$ to IL-6- and NGF-containing cultures failed to significantly alter the percentage of neurite-bearing cells compared with NGF plus IL-6 alone (Fig. 1G). Less than $5 \%$ of cells bore neurites in the presence of the trkC agonist NT-3 alone (10 pg/ml to $100 \mathrm{ng} / \mathrm{ml} ; 3.69 \pm 0.01 \%$; $18 \mathrm{hr}$ ) (Fig. $1 D, G)$, and the addition of IL-6 (10 ng/ml) or sIL-6R $(10 \mathrm{pg} / \mathrm{ml}$ to $100 \mathrm{ng} / \mathrm{ml})$ to NT3-containing cultures also failed to increase the percentage of cells displaying neurite outgrowth $(5.6 \pm 1.1 \%$ ) (Fig. $1 G$ ). Axotomy of the sciatic nerve $7 \mathrm{~d}$ before plating L4/L5 DRGs resulted in almost $80 \%$ (Fig. $1 G$ ) of neurons extending neurites, confirming that our culture protocol did not result in a significant loss of neurons.

Although IL-6 failed to initiate neurite outgrowth, its addition to neurotrophin-primed cultures resulted in dramatic neurite elongation, significantly in excess of that produced by neurotrophin exposure alone. In the presence of NGF alone (10 ng/ml; 18 hr) neurite outgrowth was characteristically dense and short (mean radius, $222 \pm 7 \mu \mathrm{m} ; n=42$ ) (Fig. $1 C, H$ ). The addition of IL-6 $(10 \mathrm{ng} / \mathrm{ml})$ after a $6 \mathrm{hr}$ exposure to NGF $(10 \mathrm{ng} / \mathrm{ml})$ resulted in dramatic morphological restructuring and significant neurite elongation compared with the effect of NGF alone $(440 \pm 21 \mu \mathrm{m}$; $n=30$ ) (Fig. $1 E, H ;{ }^{*} p<0.05, t$ test). IL-6-induced neurite elongation was independent of continuous trkA activation because elongation continued in the presence of IL-6 when NGF was sequestered with trkA-IgG. The inclusion of sIL-6R $(10 \mathrm{ng} / \mathrm{ml})$ along with IL-6 $(10 \mathrm{ng} / \mathrm{ml})$ did not significantly alter the mean neurite length $(430 \pm 20 \mu \mathrm{m})$ (Fig. $1 \mathrm{H})$ compared with cells grown in the presence of NGF $(10 \mathrm{ng} / \mathrm{ml})$ and IL-6 $(10 \mathrm{ng} / \mathrm{ml})$, which were significantly longer than those cells grown in the presence of NGF $(10 \mathrm{ng} / \mathrm{ml})$ alone (Fig. $1 H ;{ }^{* *} p<0.05, t$ test).

The effect of IL- 6 on neurite elongation was not just confined to trkA-expressing neurons. The addition of IL-6 (100 ng/ml) to NT-3-treated cultures resulted in morphological restructuring and significant neurite elongation compared with NT-3 alone (Fig. $1 F, H$ ). The mean length of neurites cultured in the presence of NT-3 plus IL-6 was significantly greater than in NT-3 alone $(401.8 \pm 18.3$ vs $145.0 \pm 6.6 \mu \mathrm{m})$ (Fig. $1 H$; $\# p<0.05, t$ test). The addition of sIL-6R $(10 \mathrm{ng} / \mathrm{ml})$ to cells cultured in the presence of IL-6 $(10 \mathrm{ng} / \mathrm{ml})$ and NT-3 $(10 \mathrm{ng} / \mathrm{ml})$ resulted in a mean neurite length of $428 \pm 22 \mu \mathrm{m}$, similar to the mean neurite extension observed from cells cultured in the presence of NT-3 $(10 \mathrm{ng} / \mathrm{ml})$ and IL-6 $(10 \mathrm{ng} / \mathrm{ml})$, but significantly longer than from cells cultured in the presence of NT-3 alone (Fig. $1 H$; \#p<0.05, $t$ test).

Furthermore, analysis of the cell size distribution of neuritebearing cells in the presence of NT-3 plus IL- 6 revealed that neurite-bearing cells were predominantly of a large caliber $(>30$ $\mu \mathrm{m}$ diameter) (Fig. $1 \mathrm{I}, \mathrm{J} ;{ }^{\star} p<0.001$, ANOVA). 


\section{Conditioning injury-induced enhanced neurite elongation is impaired in IL-6 knock-out mice}

Our data from dissociated DRGs cultures suggest a role for IL-6 in mediating enhanced growth responses of adult sensory neurons. Enhanced neurite outgrowth in vitro can be used as an index of growth status. Sensory neurons that have received a preconditioning injury in vivo display an earlier and enhanced pattern of neurite extension in comparison to intact cells (Smith and Skene, 1997; Cafferty et al., 2001). This observation is attributed to an enhanced intrinsic growth capacity. Therefore, to assess whether IL-6 plays an integral role in the conditioning lesion response, we compared the extent of neurite elongation after $18 \mathrm{hr}$ in vitro between IL- $6+/+$ and IL- $6-/-$ sensory neurons 1 week after a previous sciatic axotomy in vivo.

Dissociated adult DRGs cells from naive IL- $6+/+$ and IL- 6 - / - mice cultured in the absence of serum and trophic support failed to exhibit significant neurite extension (Fig. 2A,B,G). Trypan blue survival assay revealed that a negligible, yet equivalent, number of cells failed to survive the extraction and dissociation procedure between genotypes (IL-6 +/+, $0.01 \%$ vs IL-6 -/-, 0.01\%). Wild-type mice that had received a preconditioning injury in vivo $7 \mathrm{~d}$ earlier exhibited extensive neurite elongation, with an average length of $869 \pm 15.6 \mu \mathrm{m}$ (Fig. 2C,G). However, knock-out mice that had received a preconditioning injury exhibited a stunted neurite outgrowth response, with an average neurite extension of $321.48 \pm 20.9 \mu \mathrm{m}$ (Fig. $2 D, G$ ) significantly less than that of wild-type mice $(p<0.001$, ANOVA). Neurite extension was restored in the preinjured knock-out mice by the addition of IL-6 $(10 \mathrm{ng} / \mathrm{ml}$; $800.2 \pm 21.3 \mu \mathrm{m})$ (Fig. $2 F, G$ ). The addition of IL-6 to preinjured wild-type mice did not further enhance neurite extension $(921.2 \pm 17.3 \mu \mathrm{m})$ (Fig. 2E, G). Both wildtype and knock-out mice retained their ability to respond to NT-3 alone [10 ng/ $\mathrm{ml}$; average length of neurite extension, $455.8 \pm 18.1(+/+)$ vs $431.8 \pm 14.5 \mu \mathrm{m}$ $(-/-)]$ and in combination with IL-6 [10 $\mathrm{ng} / \mathrm{ml} ; 553.6 \pm 15.9(+/+)$ vs $510.3 \pm 15.9 \mu \mathrm{m}(-/-]$ (Fig. $2 G)$, indicating that endogenous IL- 6 has a role in initiating an alteration in growth status after a conditioning injury.

\section{Sciatic collateral projections fail to regenerate after dorsal} column lesion in IL- $6+/+$ mice

Our in vitro data suggests that IL-6 forms an integral part of the endogenous postinjury sequelae that mediates the conditioning lesion response. A preconditioning lesion to the sciatic nerve has
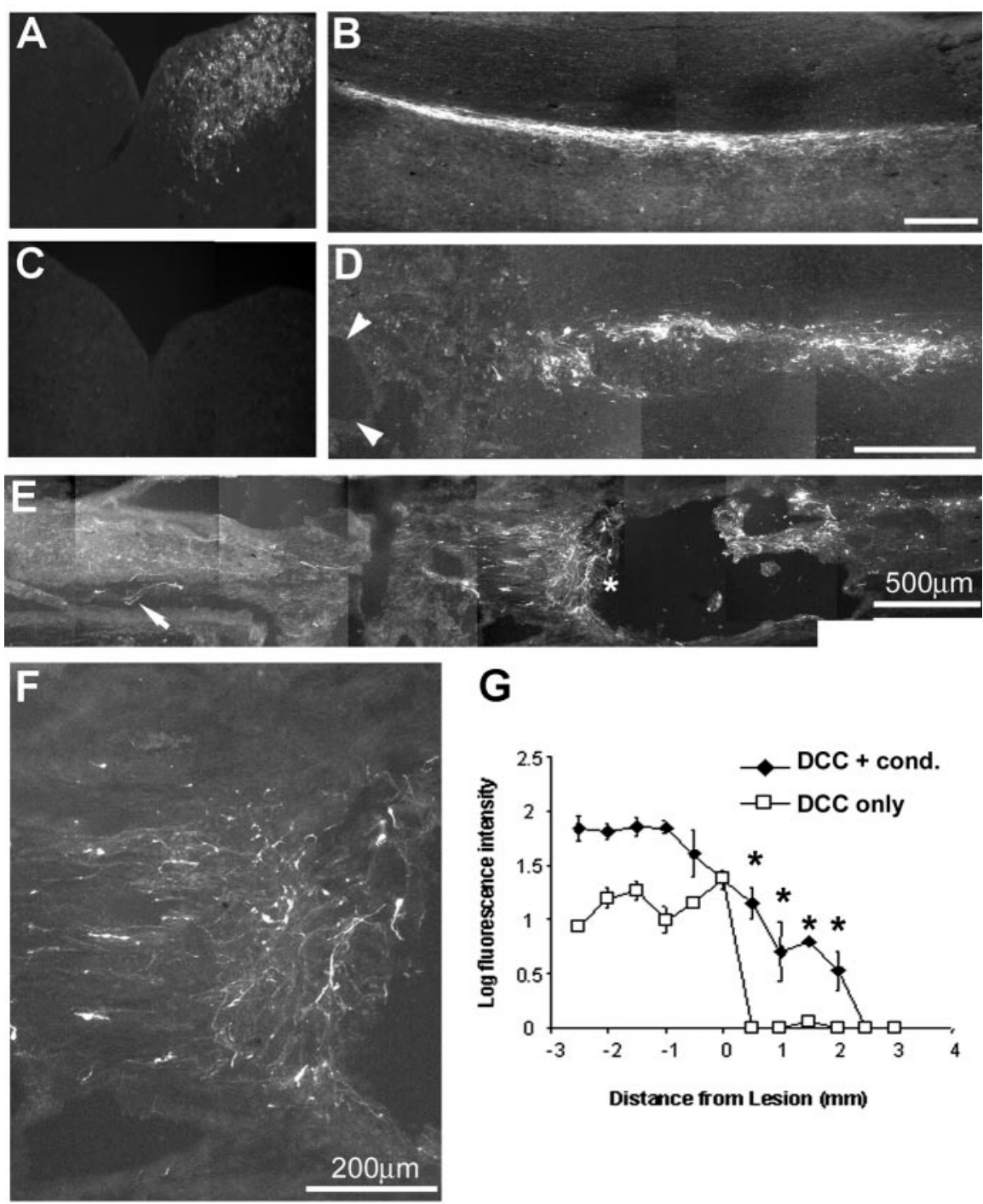

G

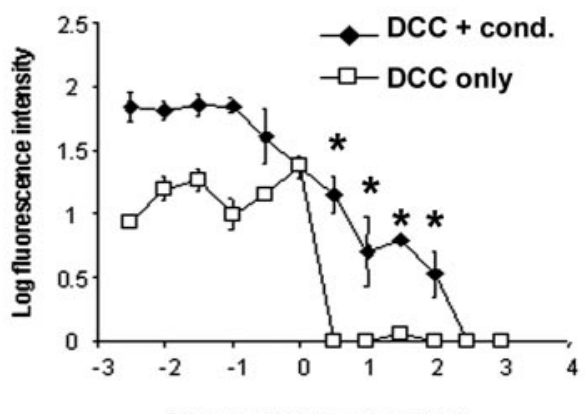

Distance from Lesion ( $(\mathrm{mm})$

Figure 3. Immunofluorescent photomicrographs of CTB-labeled sciatic nerve axon collaterals within the spinal dorsal column and gracile nucleus of the adult wild-type mouse and the effect of spinal cord injury with or without preconditioning sciatic nerve injury. Horizontal $20 \mu \mathrm{m}$ sections through the thoracic spinal cord $(B)$ and a $15 \mu \mathrm{m}$ transverse section through the gracile nucleus (A) of intact IL-6 + / + mice. The sciatic projection within the ascending dorsal column pathway visualized by CTB-IR is seen as an uninterrupted tract that projects to the ipsilateral gracile nucleus $(A)$. Four weeks after bilateral crush of the dorsal columns, the bundle of aligned fibers becomes irregular and retracts from the caudal edge of the lesion ( $D$, arrowheads). Regeneration is abortive, as indicated by the large reactive end-bulbs and the absence of labeled terminals within the gracile nucleus $(C)$. $E$, Low-power immunofluorescent photomicrograph of the lesioned IL- $6+/+$ mouse spinal cord showing regeneration of injured dorsal column fibers evoked by a preconditioning injury to the sciatic nerve $7 \mathrm{~d}$ before dorsal column crush (scale bar, $500 \mu \mathrm{m}$ ). CTB-IR fibers can be seen growing up to the cavity and are also observed in a dense plexus rostral to the lesion site (asterisk). This region of regeneration is shown in higher power in $F$ (scale bar, $200 \mu \mathrm{m}$ ). Pioneering (TB-IR axons were observed within the spinal cord white matter tracts considerable distances rostral to the lesion (arrow). In all spinal cord sections, caudal is to the right. $G$, Densitometric analysis of CTB labeling within the spinal cord 4 weeks after spinal cord injury with and without sciatic nerve preconditioning. Two-way ANOVA revealed a significant difference in CTB density between preconditioned and spinal cordlesioned animals only. Post hoc analysis (Tukey) showed that all data points rostral to the lesion site in preinjured animals were significantly different from animals with spinal cord injury alone $(p<0.001)$.

been shown to enhance the subsequent regeneration of damaged dorsal column axons (Neumann and Woolf, 1999; Qiu et al., 2002; Neuman et al., 2002). We used this paradigm to elucidate whether IL-6 is partially responsible for this enhanced growth response. Injection of a $1 \%$ solution of CTB into the left sciatic nerve of adult wild-type mice $(n=6)$ specifically labeled A fiber axons, their cell bodies in the lumbar DRGs (L4, L5, and L6), and their ascending central axon collaterals in the dorsal funiculus. CTB-IR revealed a tight, thick bundle of fibers that ascended 

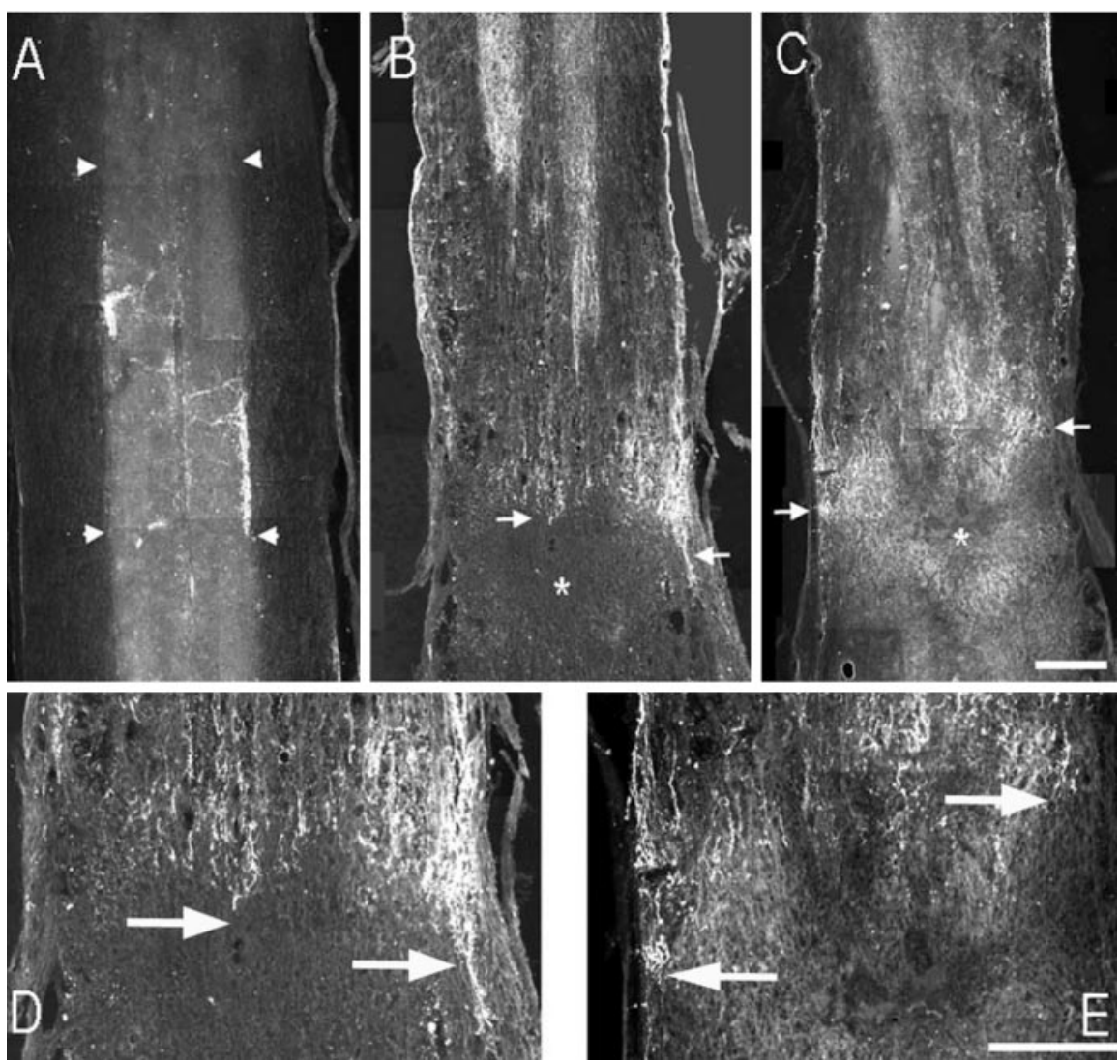

Figure 4. Immunofluorescent photomicrographs of longitudinal sections of spinal cord from wild-type and knock-out mice showing 5-HT immunoreactivity under control conditions and 4 weeks after the dorsal column lesion. $A$, Under control conditions, 5 -HT-containing terminals are entirely restricted to central gray matter regions (within arrowheads) in both IL- $6+1+$ and $-/-$ mice; $+/+$ is shown. Collateral branches extend from the medial gray border toward the spinal cord midline. $B$, In wild-type mice, 4 weeks after spinal cord injury, disruption of gray matter areas is apparent (crush marked by asterisk). Robust collateral sprouting of 5-HT-containing terminals is observed within novel regions of lateral white matter rostral to the region of spinal cord injury ( $B$; arrows). $D$, High-power photomicrograph of the crush site region. In IL-6 - / - mice, extensive collateral sprouting of 5 -HT-containing terminals is also apparent 4 weeks after spinal cord injury. Collateral sprouting is observed within white matter regions not normally occupied by descending raphe spinal axons ( $E$, arrows).

ipsilaterally in the gracile funiculus (Fig. 3B), which terminated in the gracile nucleus in the caudal medulla oblongata (Fig. $3 A$ ). A bilateral crush lesion of the dorsal column at T6 severed the entire projection, confirmed by the complete absence of CTB-IR terminals in the gracile nucleus (Fig. $3 C$ ). Four weeks after dorsal column crush, CTB-IR fibers caudal to the lesion no longer appeared as a tight dense bundle of ascending axons but appeared tangled and irregular with multidirectional sprouting (Fig. 3D). Axon density decreased dramatically on approaching the lesion site. Very few axons extended as far as the lesion (caudal edge of lesion indicated with arrowheads), and those that did stopped abruptly, forming large end bulbs with multiple varicosities. In all cases, CTB-IR fibers were not observed proximal to the lesion site.

Sciatic collaterals regenerate into and beyond the dorsal column lesion site after a prior in vivo conditioning injury in IL-6 +/+ mice

Wild-type mice that received a sciatic nerve axotomy $7 \mathrm{~d}$ before a bilateral T6 dorsal column crush displayed a markedly different pattern of CTB-labeled A fiber regeneration in comparison to non-preinjured controls (Fig. 3, compare photomicrographs in $D, E)$. Most strikingly, the density of axons immediately rostral to the lesion increased significantly (Fig. $3 E, F$ ). The regenerating fibers coursed up to the lesion in a tight fasiculated bundle, with many axons growing around the lesion perimeter and continuing into degenerating white matter rostral to the lesion. CTB-IR fibers were apparent over $2.5 \mathrm{~mm}$ past the lesion site 4 weeks after the dorsal column lesion [Fig. $3 E$ (arrow), $G]$, significantly further than axon regeneration observed in shamoperated wild-type animals that not did receive a sciatic injury (Fig. $3 D, G$; twoway ANOVA, $\left.{ }^{*} p=0.001\right)$.

\section{Collateral sprouting of uninjured} descending pathway after dorsal column lesion in IL-6 +/+ and IL-6 -/ - mice In addition to disrupting white matter tracts, dorsal column crush also compromises small regions within medial laminas III-V, known to be sites of termination of 5-HT-containing terminals of the descending raphe spinal pathway. The spinal cord injury used in this study does not, however, disrupt the descending raphe spinal 5-HT tract itself. The raphe spinal pathway is one of the only spinal cord systems with high constitutive GAP43 expression (Ching et al., 1994) and has been shown to be highly plastic after damage (Bjorklund et al., 1981). To evaluate any difference in growth permissiveness of the environment between IL- $6+/+$ and IL- 6 $-/-$ mice, we investigated raphe sprouting in the lesion area. Longitudinal sections of spinal cord from intact IL- $6+/+$ mice at lamina $\mathrm{V}$ (Fig. $4 A$ ) revealed the raphe projection entirely confined to the gray matter. Axon collaterals can be seen extending medially from the lateral gray border toward the spinal cord midline. In wild-type mice 4 weeks after spinal cord injury, the lesion site is devoid of 5-HT-IR terminals (Fig. $4 B$, asterisk), however, networks of 5-HT-IR fibers and boutons are seen rostral to the lesion site. In addition, dense networks of collaterally sprouted terminals can be seen within lateral white matter tracts rostral to the spinal cord lesion site (Fig. $4 B, D$, arrows).

Extensive collateral sprouting of 5-HT-IR fibers was also observed in IL-6 - / - mice 4 weeks after spinal cord injury. 5-HT-IR fibers were apparent rostral to the spinal cord lesion and in lateral white matter tracts rostral to the lesion site (Fig. 4C,E, arrows), GFAP-IR also failed to demonstrate any obvious differences between genotypes (data not shown). These results suggest that the prevailing environment 4 weeks after a dorsal column injury is comparable between IL- $6+/+$ and IL- $6-/-$ mice.

\section{Failure of conditioning injury-induced regeneration in IL-6 - / - mice}

Bilateral dorsal column crush injury to IL-6 -/ - mice resulted in significantly impaired regeneration of CTB-IR dorsal column fibers compared with age- and sex-matched wild-type animals (compare Figs. $3 A$ and $5 A, C$ ). Regenerating fibers in the degenerating dorsal column projection distal to the lesion site grew in a multidirectional tangled manner; the majority of 
fibers failed to reach the lesion itself (Fig. $5 A, C)$. IL-6 - / - mice that had received a preconditioning lesion to the sciatic nerve $7 \mathrm{~d}$ before the dorsal column crush produced a more robust regeneration response compared with $-/-$ mice that had received a dorsal column crush alone (Fig. $5 A, B$ ). A fasciculated bundle of CTB-IR fibers can be seen coursing up to the lesion perimeter, however, even after the preconditioning injury CTB-IR fibers were not observed rostral to the lesion site (Fig. $5 B, C$ ). The extent of preconditioning enhanced regeneration in $-/-$ mice was significantly lower than that observed from preconditioned $+/+$ animals. Fluorescent intensity analysis confirmed the significant decrease in the degree of regeneration in IL-6 - / - mice compared with IL- $6+/+$ mice after a 7-day preconditioning injury in vivo (Fig. 5C). Inspection of the dorsal column nuclei of intact (Fig. 5D) and dorsal column-lesioned (Fig. 5E) IL-6 -/mice illustrated a regular termination pattern of A fibers and a complete disruption of the projection after dorsal column injury.

Failure of axonal growth is not related to cell loss or transport deficiency in IL-6 - / - mice

There is a suggestion that, under certain circumstances, IL-6 may be neuroprotective to neurons after injury (Ikeda et al., 1996; Murphy et al., 1999). To determine whether failure of conditioning injuryinduced regeneration in IL-6 - / - mice was related to sensory neuron cell death, we examined the cell size distribution of cells in ipsilateral L4 and L5 DRGs $7 \mathrm{~d}$ after sciatic nerve transection in IL- $6+/+$ and IL-6 -/ - mice, correcting for overestimation of small and large diameter profiles by applying a recursive translation protocol (Rose and Rohrlich, 1988). No significant difference was observed in cell size distributions of L4 and L5 DRGs sensory neurons between genotypes after peripheral nerve lesions at the mid-sciatic level (Fig. 6A).

An additional explanation for the apparent regeneration deficiency in IL-6 - / - mice may arise because of differences in CTB transport rates or uptake characteristics between genotypes. Analysis of the total population and cell size distribution of cell profiles accumulating CTB $7 \mathrm{~d}$ after a peripheral lesion revealed that there was no significant difference in the proportion of profiles that transported CTB between genotypes at this time point (compare photomicrographs in Figs. 6B, 7A,F).

Growth status of sensory neurons is enhanced in IL- $6+/+$ mice but not IL-6 - / - mice after preconditioning sciatic axotomy

The preceding data suggest that the lack of regeneration in IL-6 $-/-$ mice is not a result of cell loss or CTB transport deficiency.
One possibility, therefore, is an alteration in the inherent growth capacity of sensory neurons after conditioning nerve lesions. To address this issue, we have determined the degree of expression of growth-associated peptide (GAP43) in CTB accumulating neurons after conditioning lesions in IL- $6+/+$ and IL- $6-/-$ mice. GAP43 is highly expressed in the cell bodies of developing and regenerating sensory neurons and, in the adult, has been used as an index of growth status (Schreyer and Skene, 1991, 1993). To determine the growth status of CTB transporting fibers, dual immunohistochemistry was performed for GAP43 and CTB on four randomly selected sections from L4 and L5 ganglia from IL-6 $+/+$ and IL- $6-/-$ mice ( $n=6$ per genotype) that had received a preconditioning injury to the sciatic nerve, or sham surgery ( $n=3$ per genotype) $7 \mathrm{~d}$ before dorsal column crush. Consistent with the findings of Andersen and Schreyer (1999), qualitatively, three different levels of GAP43 expression were observed. Under normal circumstances in the absence of injury, a large percentage of cells contain a low level of GAP43 expression (Fig. 7E,J) (Schreyer and Skene, 1991). Elevated expression levels are only 

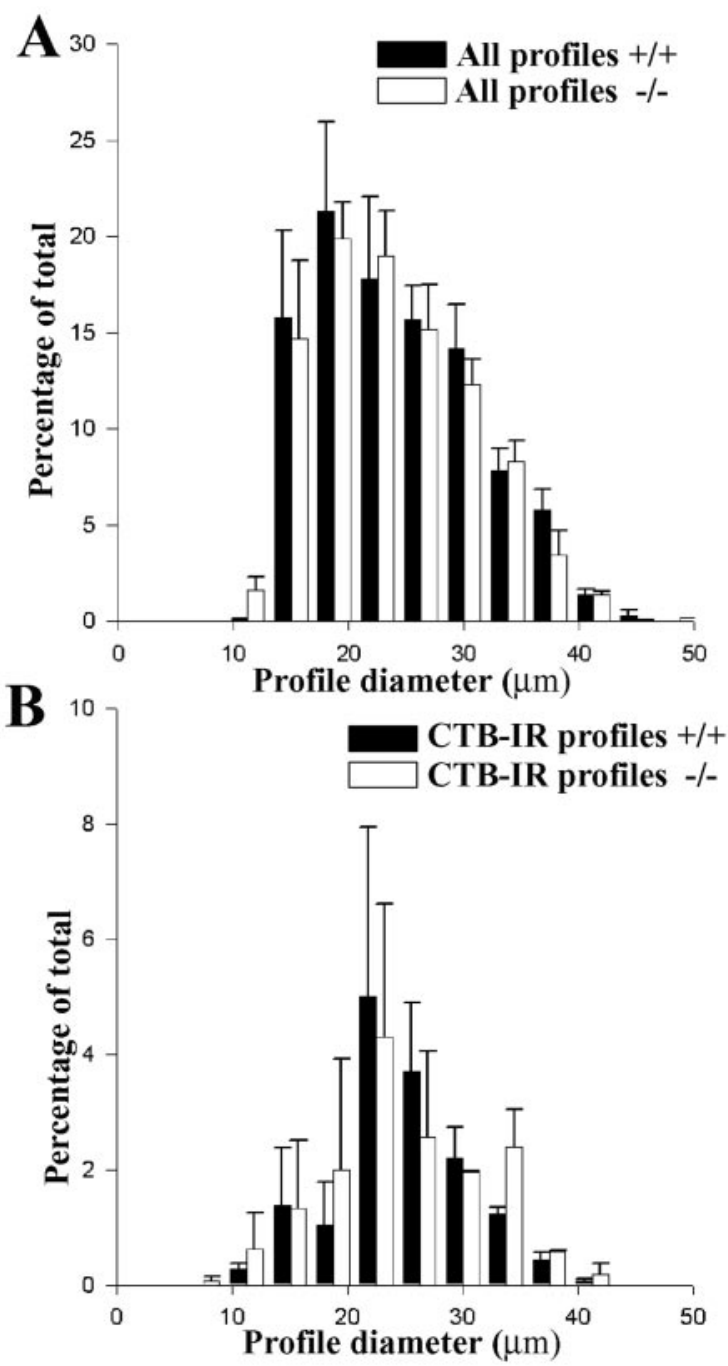

Figure 6. Sciatic axotomy does not result in differential sensory neuron cell loss in IL-6 $+/+$ or $-/-$ mice. Applying a recursive translation protocol, we examined the cell size distribution of all cell profiles in ipsilateral L4 and L5 DRG $7 \mathrm{~d}$ after sciatic nerve transection in IL- $6+/+$ and $-/-$ mice ( $A$ ). No significant difference was observed in cell size distributions of $L 4$ and L5 DRG sensory neurons between genotypes after peripheral nerve lesions at the mid-sciatic level. $B, C T B$ transport in sciatic afferents is not significantly different in IL- $6+/+$ mice compared with $-/-$ mice. The graph shows that the cell size distributions of CTB-IR profiles in $+/+$ and $-1-$ mice are equivalent.

seen after a peripheral nerve injury. We have concentrated analysis on those CTB accumulating neuronal profiles expressing high levels of GAP43 only as an index of their enhanced regenerative potential. In IL- $6+/+$ mice, a significant upregulation of GAP43 expression levels were observed in preconditioned DRGs compared with sham-operated or contralateral intact ganglia (Fig. $7 B-D, K$; two-way ANOVA, $p=0.001$ ). However, inspection of L4 and L5 ganglia from IL-6 - / - mice that had received a conditioning injury failed to show an upregulation of GAP43 expression in comparison with sham-operated or contralateral control ganglia (Fig. 7G-I,K). Expression of GAP43 was comparable in L4 and L5 ganglia between sham-operated animals and contralateral ganglia from animals that had received a preconditioning injury (data not shown). It is likely that this lack of GAP43 expression within CTB accumulating neuronal profiles correlates with the reduced regeneration capacity of damaged dorsal column axon collaterals from IL- $6-/-$ mice.

\section{Discussion}

IL-6 promotes a distinct "elongation" phase of axon growth in adult sensory neurons in vitro

One of the key determinants of CNS regenerative failure is the purportedly low inherent growth capacity of injured adult CNS neurons. Along with the prevailing hostile environment associated with the damaged CNS, axon regeneration is, at best, abortive. One strategy, therefore, to enhance regeneration would be to boost the growth status of damaged axons. It has been reported that enhanced regeneration of injured dorsal column fibers observed after a peripheral conditioning lesion is as a result of a boosted growth capacity (Richardson and Issa, 1984; Neumann and Woolf, 1999; Pasterkamp et al., 2001). The factors that mediate the phenotypic switch of axonal cell bodies from homeostasis to an active growth mode are yet to be fully determined. This study provides evidence to suggest that the gp130 cytokine IL-6 fulfills this role as a factor capable of altering the growth capacity of regenerating sensory neurons both in vitro and in vivo.

We have confirmed previous observations that two distinct modes of adult sensory neuron outgrowth are clearly observed in vitro: an initial neurotrophin-dependant (Mohiuddin et al., 1995; Gavazzi et al., 1999) neurite outgrowth stage, characterized by highly branched processes with limited linear extension, and a subsequent neurotrophin-independent, elongating, or regenerative growth phase (Smith and Skene, 1997; Cafferty et al., 2001). Previous work from this laboratory has highlighted the integral role played by another member of the gp130 cytokines in mediating the secondary or elongating growth phase. LIF, absent from the adult nervous system is injury upregulated in the periphery, retrogradely transported back to the DRGs, where it alters the intrinsic growth status of regenerating peripherally directed sensory axons in a manner dependent on the activation of signal transducers and activators of transcription 3 (STAT-3) (Gardiner et al., 2000, 2001; Cafferty et al., 2001). Although all sensory neurons express the gp130 receptor, only small diameter cells express cytoplasmic gp190 (LIF receptor) after injury (Gardiner et al., 2002); hence, the effect of LIF is specific to un-myelinated small caliber neurons. Whereas LIF requires heterodimerization of gp130 and gp190 to elicit its effects, IL- 6 requires the presence of its high-affinity soluble receptor $\alpha$ subunit and subsequent homodimerization of gp130 subunits. The fact that all sensory neurons express gp130 confers the ability of IL- 6 to bind these neurons.

IL-6 failed to initiate neurite outgrowth in cultures of acutely dissociated adult rat sensory neurons in the presence or absence of is its soluble receptor. However, inclusion of IL-6 to cultures grown in the presence of neurotrophic factors (NGF or NT-3) resulted in dramatic neurite elongation. Application of IL-6 to cultures primed with NGF or NT-3 failed to recruit a growth response from an additional population of cells; the percentage of neurons responding with an enhanced growth pattern was appropriate to the percentage of neurons expressing the requisite trk receptors (trkA and trkC, respectively). Most importantly, cells that illustrated elongating or a regenerative growth pattern cultured in the presence of NT-3 and IL- 6 were predominantly large in diameter, the same population with central collaterals that form the dorsal column projection. The enhanced growth pattern and average length of neurite extension observed after neurotrophin plus IL-6 treatment was similar to cells that had been preinjured in vivo. To evaluate whether IL- 6 was capable of endogenously elevating the growth status of damaged sensory neurons, we observed the average length of neurite extension of 

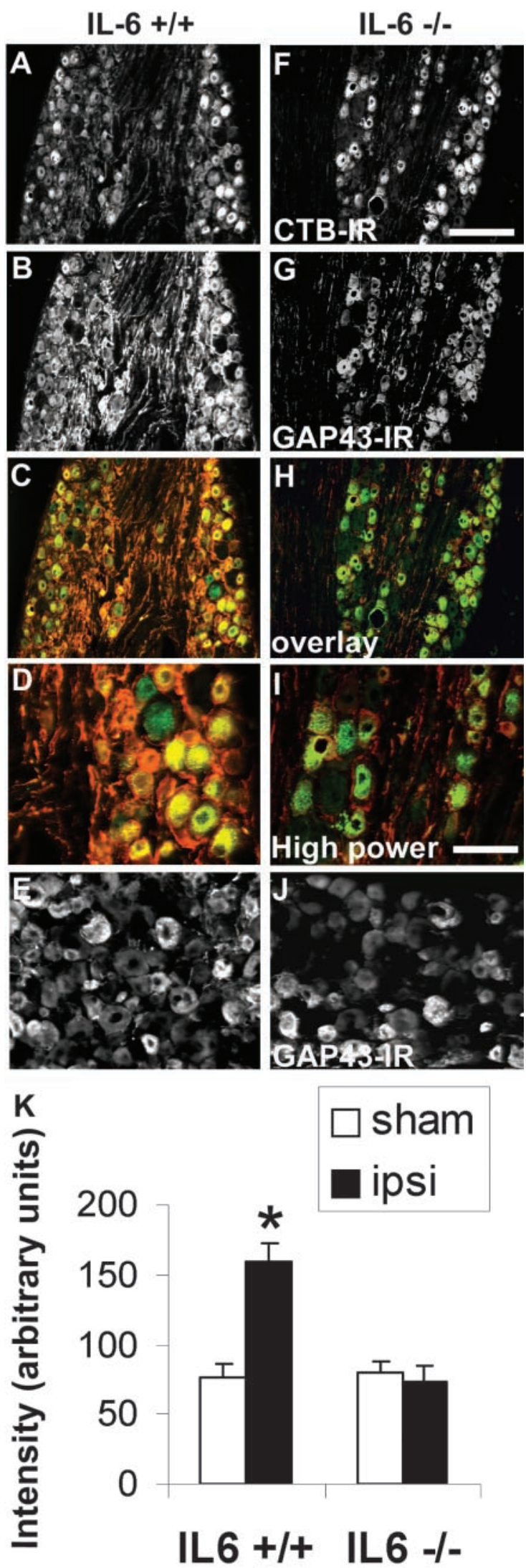

Figure 7. Sciatic axotomy fails to increase $L 5$ DRGs GAP43 levels in IL-6 - / - mice. Photomicrographs of L5 DRGs sections from IL- $6+/+(A-E)$ and IL- $6-/-(F-J)$ mice 5 weeks after sciatic nerve axotomy colabeled with antibodies against $C$ TB and GAP43. $A$ and $F$ show CTB-IR and represent cell bodies of injured sciatic afferent fibers, the collaterals of which were transganglionically traced and subsequently revealed in the spinal cord. $B$ and $G$ illustrate
DRGs cells cultured from IL- $6-/-$ and IL- $6+/+$ mice $7 \mathrm{~d}$ after a sciatic axotomy. Preinjured cells from the wild-type animals exhibited a classic pattern of elongating neurite extension, whereas neurite elongation was dramatically stunted from knock-out mice. The lack of IL-6 availability in vivo is the most parsimonious explanation for this observation because of the fact that both wild-type and knock-out mice retained the ability to respond to the exogenous application of neurotrophins and IL-6.

One question, crucial to our findings, is whether or not gp 130 cytokines and neurotrophins are locally available to injured sensory neurons after injury in vivo. This is indeed the case. After sciatic nerve axotomy in vivo, IL-6 is rapidly expressed at the site of peripheral nerve injury and indeed within large diameter sensory neurons (Bolin et al., 1995; Murphy et al., 1995; Bourde et al., 1996). Both NGF and NT3 have also been shown to be induced within axotomized DRGs and localized to satellite glial cells (Zhou et al., 1999). It is likely, therefore, that all of these factors would be available for both initiation of axon growth (NGF, NT3) and sustained long axon regeneration (IL-6) after axonal damage. The availability of IL-6, while beneficial to sensory neurons in the periphery (Murphy et al., 2000), appears to have deleterious consequences in the CNS. Intrathecal infusion of IL-6 (Thompson and Cafferty, 1999) and other gp130 cytokines (Thompson et al., 1996) results in the emergence of neuropathic pain states, a possible consequence of IL-6-induced BDNF spinal synaptic plasticity (Kerr et al., 1999). This differential action of IL-6 highlights a local action of injury-regulated cytokines, a point elegantly reviewed by Hauben and Schwartz (2003), who outlined the spatial and temporal progression of inflammation after spinal cord injury and crucially highlighted local immune responses that have vastly differential implications.

\section{Conditioning injury-induced axon regeneration fails in the} CNS of IL-6 - / - mice

The rodent dorsal column projection is formed from centrally projecting $A \beta$ fiber collaterals from both the forelimb (cuneate funiculus) and hind limb (gracile funiculus). A $\beta$ fibers convey sensory information pertaining to fine-touch discrimination, vibration, and conscious proprioception; their cell bodies reside in the DRGs and are broadly classified as large diameter myelinated cells. The dorsal column projection is typical of all CNS white matter tracts, in that it fails to regenerate after lesion. Damage results in axonal disruption, glial proliferation, and secondary degeneration of the damaged area and the creation of a scar that appears to be impenetrable to regenerating axons. However, preconditioning lesions have been shown to enhance regeneration of dorsal column axons (Richardson and Issa, 1984; Neumann and Woolf, 1999).

Because of the observation that IL- 6 in the presence of NT-3 can produce an enhanced growth response from a population of large diameter sensory neurons (presumably A $\beta$ fibers) and, furthermore, that conditioning injury-enhanced regeneration of dorsal column $\mathrm{A} \beta$ collateral branches within the CNS is diminished in the absence of IL- 6 , we introduced the role of IL- 6 as the

GAP43-IR. Cand H show the pseudo-colored overlay (yellow) of the two antibodies (CTB, green; GAP43, red). Significantly higher numbers of (TB-IR cell profiles display high levels of GAP43 in IL-6 $+/+$ mice compared with $-/-$ mice (compare $($ and $H$ with $K$ ) after sciatic axotomy, in comparison with their sham-operated controls $(E, J, K)$. $K$ illustrates that CTB-IR profiles in $L 5$ DRGs from IL-6 + / + mice express higher levels of GAP43-IR after a preconditioning injury in comparison with sham-operated controls, whereas preconditioning injury to IL-6 - I- mice failed to elevate GAP43 levels. Scale bars: $A-C, F-H, 100 \mu \mathrm{m} ; D, E, I, J, 50 \mu \mathrm{m}$. 
factor crucial in mediating conditioning lesion-induced enhanced axonal regeneration.

There are several possibilities that may account for our observations. First, it is possible that reduced regeneration of dorsal column axons is attributable to cell loss and atrophy that might be associated with peripheral nerve axotomy (Knyihar-Csillik et al., 1987; Tandrup et al., 2000). To test this, we analyzed the viability of sensory neurons 5 weeks after sciatic axotomy (the time point used in this study) and revealed that there was no significant difference among all subpopulations of DRGs neurons between IL- $6+/+$ and $-/-$ mice. Second, it is also a possibility that there is a difference in axonal transport between $+/+$ and $-/-$ mice. We also showed that this is not the case because, at the time point studied, there was no significant difference in the proportion of sensory neurons transporting CTB between genotypes.

Third, it is possible that the CNS glial environment and its response to injury are different between IL- $6+/+$ and $-/-$ mice. Damage to the spinal cord leads to disruption of myelin structure, and, consequently, injured axons are exposed to inhibitory molecules that are normally localized within myelin membrane envelopes, such as MAG and Nogo (for review, see Qiu et al., 2002; McGee and Strittmatter, 2003). CNS lesions also result in the formation of glial scar tissue that presents a physical as well as a molecular barrier for regenerating axons. Reactive astrocytes, the main component of glial scars, are known to express a number of boundary molecules, such as tenascin, keratin, and chondroitin sulfate proteoglycans, that further restrict axonal regeneration (Davies et al., 1997, 1999; Fitch and Silver, 1997; Fawcett and Asher, 1999; Bradbury et al., 2002). IL-6 is known to be a major contributor to injury-induced spinal gliosis (Klein et al., 1997; Fitch et al., 1999; Penkowa et al., 1999; Tilgner et al., 2001). Indeed, a recent study has shown discrete IL-6 expression within the lesion site after contusion injury to the spinal cord in the absence of any other peripheral or central lesion (Song et al., 2001). This study also illustrated an upregulation of two inhibitors of IL-6 signaling, SOCS-2 and SOCS-3 (suppressor of cytokine signaling 2 and 3), thereby indicating that the effects of IL-6 maybe sensitively regulated and a balance that possibly fails after injury, thereby allowing IL-6 to recruit a profound inflammatory response that could result in large-scale neurodegeneration. Available evidence to date, therefore, suggests that the absence of IL- 6 from the spinal cord injury site would be potentially beneficial in terms of neuroprotection and regeneration (Fitch et al., 1999; Van Wagoner and Benveniste, 1999; Fisher et al., 2001). However, regeneration of dorsal column axons fails in both IL-6 $+/+$ and IL-6 -/ - mice, illustrating that the lesion environment of the knock-out is as equally hostile as it appears in the wild type. The converse to this theory could also be true that the spinal cord environment of IL-6 null mutant mice is totally nonpermissive to neurite growth, independent of the inherent growth status of injured neurons. We have further shown that this is not the case. Injury to dorsal column white matter tracts used in the present study also disrupts areas of medial gray matter known to be sites of termination of descending 5-HT raphe spinal neurons. Descending axons of this raphe spinal system remain undamaged in this model of spinal cord injury. These neurons express high intrinsic GAP43 levels, and intact 5-HT pathways have been shown to readily reinnervate areas vacated by both damaged 5-HT-containing and non-5-HT-containing fibers (Bjorklund et al., 1981; Zhou and Azmitia, 1986; Ching et al., 1994). In both IL- $6+/+$ and IL-6 - / - mice, collateral sprouting of 5-HTpositive terminals occurred into novel white matter regions. We have shown, therefore, that the collateral sprouting of an undam- aged descending raphe spinal system takes place to the same degree in $-/-$ and $+/+$ mice, thereby indicating that the spinal injury environment of IL- $6-/-$ mice is comparable with that of wild-type mice.

Our data suggest that conditioning injury-enhanced regeneration fails in IL-6 -/ - mice because of their inability to increase growth status in damaged sensory neurons. First, the expression of GAP43, a universal indicator of neuronal growth status, is significantly upregulated in axotomized DRGs neurons in IL-6 $+/+$ but not $-/-$ mice. GAP43 is widely expressed during axonal outgrowth in development but is significantly downregulated once pathfinding is complete (Dani et al., 1991; Reynolds et al., 1991). In the adult, GAP43 expression is significantly elevated in response to peripheral, but not central, axon lesions (Schreyer and Skene, 1991; Chong et al., 1994), and upregulated protein is transported along dorsal column axons (Schreyer and Skene, 1991). The differential response of GAP43 expression after injury has been associated with differential regenerative potential of PNS and CNS tissues. Thus, increased expression of GAP43 has been used as an indicator of enhanced growth status and regeneration. Interestingly, overexpression of GAP43 and another family member, CAP23, in transgenic mice has been shown to mimic the effect of conditioning lesion and induce regeneration of injured central axons in vivo (Bomze et al., 2001).

Our data support the established notion that inhibitory signals within the damaged CNS that present a barrier to regenerating axons can be mostly overcome by boosting the intrinsic growth status of the regenerating fibers (Davies et al., 1997, 1999; Neumann and Woolf, 1999; Pasterkamp et al., 2001; for review, see Snider et al., 2002). Our observations further support the accumulating data (Gardiner et al., 2000, 2001; Liu and Snider, 2001; Snider et al., 2002) suggesting that such an increase in growth status may require gp130-dependent STAT-3 phosphorylation. Indeed, STAT-3 may provide a convergent link to other pathways known to enhance growth status. Recent reports from Qiu et al. (2002) and Neumann et al. (2002) identified a role for cAMP in mediating conditioning lesion-enhanced regeneration of dorsal column axons. cAMP has been shown to activate STAT-3 directly and enhance IL-6 expression in cardiac myocytes (Yin et al., 2003) and may have a similar role in sensory neurons after peripheral injury, a process that may be uncoupled after CNS injury. Furthermore, understanding of the gp130initiated signaling pathways that enhance growth capacity and enable growth within a CNS lesion environment may aid the design of therapeutic strategies to promote CNS regeneration.

\section{References}

Andersen LB, Schreyer DJ (1999) Constitutive expression of GAP-43 correlates with rapid, but not slow regrowth of injured dorsal root axons in the adult rat. Exp Neurol 155:157-164.

Bjorklund A, Wiklund L, Descarries L (1981) Regeneration and plasticity of central serotonergic neurons: a review. J Physiol (Paris) 77:247-255.

Bolin LM, Verity AN, Silver JE, Shooter EM, Abrams JS (1995) Interleukin- 6 production by Schwann cells and induction in sciatic nerve injury. J Neurochem 64:850-858.

Bomze HM, Bulsara KR, Iskandar BJ, Caroni P, Skene JH (2001) Spinal axon regeneration evoked by replacing two growth cone proteins in adult neurons. Nat Neurosci 4:38-43.

Bourde O, Kiefer R, Toyka KV, Hartung HP (1996) Quantification of interleukin-6 mRNA in Wallerian degeneration by competitive reverse transcription polymerase chain reaction. J Neuroimmunol 69:135-140.

Bradbury EJ, Khemani S, Von R, King, Priestley JV, McMahon SB (1999) NT-3 promotes growth of lesioned adult rat sensory axons ascending in the dorsal columns of the spinal cord. Eur J Neurosci 11:3873-3883.

Bradbury EJ, Moon LD, Popat RJ, King VR, Bennett GS, Patel PN, Fawcett 
JW, McMahon SB (2002) Chondroitinase ABC promotes functional recovery after spinal cord injury. Nature 416:636-640.

Cafferty WB, Gardiner NJ, Gavazzi I, Powell J, McMahon SB, Heath JK, Munson J, Cohen J, Thompson SW (2001) Leukemia inhibitory factor determines the growth status of injured adult sensory neurons. J Neurosci 21:7161-7170.

Carlsen RC (1983) Delayed induction of the cell body response and enhancement of regeneration following a condition/test lesion of frog peripheral nerve at 15 degrees C. Brain Res 279:9-18.

Ching YP, Averill S, Wilkin GP, Wotherspoon G, Priestley JV (1994) Serotonergic terminals express a growth associated protein (GAP-43) in the adult rat spinal cord. Neurosci Lett 167:67-72.

Chong MS, Reynolds ML, Irwin N, Coggeshall RE, Emson PC, Benowitz LI, Woolf CJ (1994) GAP-43 expression in primary sensory neurons following central axotomy. J Neurosci 14:4375-4384.

Chong MS, Woolf CJ, Turmaine M, Emson PC, Anderson PN (1996) Intrinsic versus extrinsic factors in determining the regeneration of the central processes of rat dorsal root ganglion neurons: the influence of a peripheral nerve graft. J Comp Neurol 370:97-104.

Dani JW, Armstrong DM, Benowitz LI (1991) Mapping the development of the rat brain by GAP-43 immunocytochemistry. Neuroscience 40:277-287.

Davies SJ, Fitch MT, Memberg SP, Hall AK, Raisman G, Silver J (1997) Regeneration of adult axons in white matter tracts of the central nervous system. Nature 390:680-683.

Davies SJ, Goucher DR, Doller C, Silver J (1999) Robust regeneration of adult sensory axons in degenerating white matter of the adult rat spinal cord. J Neurosci 19:5810-5822.

Fawcett JW, Asher RA (1999) The glial scar and central nervous system repair. Brain Res Bull 49:377-391.

Fisher J, Mizrahi T, Schori H, Yoles E, Levkovitch-Verbin H, Haggiag S, Revel M, Schwartz M (2001) Increased post-traumatic survival of neurons in IL-6 knockout mice on a background of EAE susceptibility. J Neuroimmunol 119:1-9.

Fitch MT, Silver J (1997) Activated macrophages and the blood-brain barrier: inflammation after CNS injury leads to increases in putative inhibitory molecules. Exp Neurol 148:587-603.

Fitch MT, Doller C, Combs CK, Landreth GE, Silver J (1999) Cellular and molecular mechanisms of glial scarring and progressive cavitation: in vivo and in vitro analysis of inflammation-induced secondary injury after CNS trauma. J Neurosci 19:8182-8198.

Gardiner NJ, Cafferty WB, Thompson SW (2000) LIF-induced neurite elongation is associated with STAT-3 activation in rat dorsal root ganglion neurons. Soc Neurosci Abstr 26:27.14.

Gardiner NJ, Cafferty WB, Thompson SW (2001) Leukemia inhibitory factor (LIF) induces neurite elongation in rat dorsal root ganglia neurons in vitro by activation of the JAK-STAT pathway. J Physiol (Lond) 531:531546.

Gardiner NJ, Cafferty WBJ, Slack SE, Thompson SWN (2002) Expression of gp130 and leukemia inhibitory factor receptor subunits in adult rat sensory neurons: regulation by nerve injury. J Neurochem 83:100-109.

Gavazzi I, Kumar RD, McMahon SB, Cohen J (1999) Growth responses of different subpopulations of adult sensory neurons to neurotrophic factors in vitro. Eur J Neurosci 11:3405-3414.

Hauben E, Schwartz M (2003) Therapeutic vaccination for spinal cord injury: helping the body to cure itself. Trends Pharmacol 24:7-12.

Hirota H, Kiyama H, Kishimoto T, Taga T (1996) Accelerated nerve regeneration in mice by upregulated expression of interleukin (IL) 6 and IL-6 receptor after trauma. J Exp Med 183:2627-2634.

Ikeda K, Kinoshita M, Tagaya N, Shiojima T, Taga T, Yasukawa K, Suzuki H, Okano A (1996) Coadministration of interleukin-6 (IL-6) and soluble IL-6 receptor delays progression of wobbler mouse motor neuron disease. Brain Res 726:91-97.

Kerr BJ, Bradbury EJ, Bennett DL, Trivedi PM, Dassan P, French J, Shelton DG, McMahon SB, Thompson SW (1999) Brain-derived neurotrophic factor modulates nociceptive sensory inputs and NMDA-evoked responses in the rat spinal cord. J Neurosci 19:5138-1548.

Klein MA, Moller JC, Jones LL, Bluethmann H, Kreutzberg GW, Raivich G (1997) Impaired neuroglial activation in interleukin-6 deficient mice. Glia 19:227-233.

Knyihar-Csillik E, Rakic P, Csillik B (1987) Transganglionic degenerative atrophy in the substantia gelatinosa of the spinal cord after peripheral nerve transection in rhesus monkeys. Cell Tissue Res 247:599-604.
Kopf M, Baumann H, Freer G, Freudenberg M, Lamers M, Kishimoto T, Zinkernagel R, Bluethmann H, Kohler G (1994) Impaired immune and acute-phase responses in interleukin-6-deficient mice. Nature 368:339-342.

Kurek JB, Austin L, Cheema SS, Bartlett PF, Murphy M (1996) Upregulation of leukaemia inhibitory factor and interleukin-6 in transected sciatic nerve and muscle following denervation. Neuromuscul Disord 6:105-114.

Lindsay RM (1988) Nerve growth factors (NGF,BDNF) enhance axonal regeneration but are not required for survival of adult sensory neurons. J Neurosci 8:2394-2405.

Liu RY, Snider WD (2001) Different signaling pathways mediate regenerative versus developmental sensory axon growth. J Neurosci 21:RC164(1-5).

McGee AW, Strittmatter SM (2003) The Nogo-66 receptor: focusing myelin inhibition of axon regeneration. Trends Neurosci 26:193-198.

McQuarrie IG, Grafstein B (1973) Axon outgrowth enhanced by a previous nerve injury. Arch Neurol 29:53-55.

McQuarrie IG, Grafstein B, Gershon MD (1977) Axonal regeneration in the rat sciatic nerve: effect of a conditioning lesion and of dbcAMP. Brain Res 132:443-453.

Mohiuddin L, Fernandez K, Tomlinson DR, Fernyhough P (1995) Nerve growth factor and neurotrophin-3 enhance neurite outgrowth and upregulate the levels of messenger RNA for growth-associated protein GAP-43 and T alpha 1 alpha-tubulin in cultured adult rat sensory neurones. Neurosci Lett 185:20-23.

Murphy PG, Grondin J, Altares M, Richardson PM (1995) Induction of interleukin-6 in axotomized sensory neurons. J Neurosci 15:5130-5138.

Murphy PG, Borthwick LS, Johnston RS, Kuchel G, Richardson PM (1999) Nature of the retrograde signal from injured nerves that induces interleukin-6 mRNA in neurons. J Neurosci 19:3791-3800.

Murphy PG, Borthwick LA, Altares M, Gauldie J, Kaplan D, Richardson PM (2000) Reciprocal actions of interleukin-6 and brain-derived neurotrophic factor on rat and mouse primary sensory neurons. Eur J Neurosci 12:1891-1899.

Neumann S, WoolfCJ (1999) Regeneration of dorsal column fibers into and beyond the lesion site following adult spinal cord injury. Neuron 23:83-91.

Neumann S, Bradke F, Tessier-Lavigne M, Basbaum AI (2002) Regeneration of sensory axons within the injured spinal cord induced by intraganglionic cAMP elevation. Neuron 34:885-893.

Oudega M, Varon S, Hagg T (1994) Regeneration of adult rat sensory axons into intraspinal nerve grafts: promoting effects of conditioning lesion and graft predegeneration. Exp Neurol 129:194-206.

Pasterkamp RJ, Anderson PN, Verhaagen J (2001) Peripheral nerve injury fails to induce growth of lesioned ascending dorsal column axons into spinal cord scar tissue expressing the axon repellent Semaphorin3A. Eur J Neurosci 13:457-471.

Penkowa M, Moos T, Carrasco J, Hadberg H, Molinero A, Bluethmann H, Hidalgo J (1999) Strongly compromised inflammatory response to brain injury in interleukin-6-defiecient mice. Glia 25:343-357.

Qiu J, Cai D, Dai H, McAtee M, Hoffman PN, Bregman BS, Filbin MT (2002) Spinal axon regeneration induced by elevation of cyclic AMP. Neuron 34:895-903.

Reichert F, Levitzky R, Rotshenker S (1996) Interleukin 6 in intact and injured mouse peripheral nerves. Eur J Neurosci 8:530-535.

Reynolds ML, Fitzgerald M, Benowitz LI (1991) GAP-43 expression in developing cutaneous and muscle nerves in the rat hindlimb. Neuroscience 41:201-211.

Richardson PM, Issa VM (1984) Peripheral injury enhances central regeneration of primary sensory neurones. Nature 309:791-793.

Richardson PM, Verge VM (1987) Axonal regeneration in dorsal spinal roots is accelerated by peripheral axonal transection. Brain Res 411:406-408.

Rose RD, Rohrlich D (1988) Counting sectioned cells via mathematical reconstruction. J Comp Neurol 272:365-386.

Schreyer DJ, Skene JH (1991) Fate of GAP-43 in ascending spinal axons of DRG neurons after peripheral nerve injury: delayed accumulation and correlation with regenerative potential. J Neurosci 11:3738-3751.

Schreyer DJ, Skene JH (1993) Injury-associated induction of GAP-43 expression displays axon branch specificity in rat dorsal root ganglion neurons. J Neurobiol 24:959-970.

Sjoberg J, Kanje M (1990) The initial period of peripheral nerve regenera- 
tion and the importance of the local environment for the conditioning lesion effect. Brain Res 529:79-84.

Smith DS, Skene JH (1997) A transcription-dependent switch controls competence of adult neurons for distinct modes of axon growth. J Neurosci 17:646-658.

Snider WD, Zhou FQ, Zhong J, Markus A (2002) Signaling the pathway to regeneration. Neuron 35:13-16.

Song G, Cechvala C, Resnick DK, Dempsey RJ, Rao VL (2001) GeneChip analysis after acute spinal cord injury in the rat. J Neurochem 79:804-815.

Tandrup T, Woolf CJ, Coggeshall RE (2000) Delayed loss of small dorsal root ganglion cells after transection of the rat sciatic nerve. J Comp Neurol 422:172-180.

Thompson SWN, Dray A, Urban L (1996) Leukemia inhibitory factor induces mechanical allodynia but not thermal hyperalgesia in the juvenile rat. Neuroscience 4:1091-1094.

Thompson SWN, Cafferty WBJ (1999) Gp 130 receptor activation induces mechanical hypersensitivity but not thermal hyperalgesia in the adult rat. Soc Neurosci Abstr 25:609.15.

Tilgner J, Volk B, Kaltschmidt C (2001) Continuous interleukin-6 applica- tion in vivo via macroencapsulation of interleukin-6-expressing COS-7 cells induces massive gliosis. Glia 35:234-245.

Van Wagoner NJ, Benveniste EN (1999) Interleukin-6 expression and regulation in astrocytes. J Immunol 100:124-139.

Yin F, Li P, Zheng M, Chen L, Xu Q, Chen K, Wang YY, Zhang YY, Han C (2003) Interleukin-6 family of cytokines mediates isoproterenol-induced delayed STAT3 activation in mouse heart. J Biol Chem 278:201070-201075.

Zhong J, Heumann R (1995) Lesion-induced interleukin-6 mRNA expression in rat sciatic nerve. Ann NY Acad Sci 762:488-490.

Zhong J, Dietzel ID, Wahle P, Kopf M, Heumann R (1999) Sensory impairments and delayed regeneration of sensory axons in interleukin-6deficient mice. J Neurosci 19:4305-4313.

Zhou FC, Azmitia EC (1986) Induced homotypic sprouting of serotonergic fibres in hippocampus II: an immunocytochemistry study. Brain Res 373:337-348.

Zhou XF, Deng YS, Chie E, Xue Q, Zhong JH, McLachlan EM, Rush RA, Xian CJ (1999) Satellite-cell-derived nerve growth factor and neurotrophin-3 are involved in noradrenergic sprouting in the dorsal root ganglia following peripheral nerve injury in the rat. Eur J Neurosci 11:1711-1722. 